\title{
PPAR $\alpha$ Agonist Stimulated Angiogenesis by Improving Endothelial Precursor Cell Function Via a NLRP3 Inflammasome Pathway
}

\author{
Yaping Deng ${ }^{b}$ Xue Han ${ }^{b}$ Zheng Yao a, Yuannan Sun $^{b} \quad$ Jiawen Yu ${ }^{b}$ Jian Cai ${ }^{b}$ \\ Guofei Ren ${ }^{b}$ Guojun Jiang ${ }^{b}$ Feng Han ${ }^{a}$ \\ aInstitute of Pharmacology and Toxicology, College of Pharmaceutical Sciences, Zhejiang University, \\ Hangzhou, Zhejiang, 'Department of Pharmacy, Zhejiang Xiaoshan Hospital, Hangzhou, Zhejiang, \\ China
}

\section{Key Words}

PPAR $\alpha$ agonist • Angiogenesis • Endothelial precursor cell • NLRP3 inflammasome

\begin{abstract}
Background: Impaired wound healing is a common complication of diabetes and is the leading cause of lower extremity amputation. Treatment with fenofibrate, a peroxisome proliferatoractivated receptor $\alpha$ (PPAR $\alpha)$ agonist, was associated with a lower risk of amputations, particularly minor amputations without known large-vessel diseases, probably through nonlipid mechanisms. The current study aimed to test our hypothesis that fenofibrate stimulates angiogenesis and restores endothelial precursor cell (EPC) function via inhibiting Nod-like receptor protein 3 (NLRP3) inflammasome in streptozotocin (STZ)-induced diabetic mice. Methods: Male C57BL/6 mice were randomly divided into three groups: control, STZ-induced diabetic mice and fenofibrate treated diabetic group. Wound closure was assessed by wound area and CD31 positive capillaries. Both the migration and tube formation capacities of EPCs were measured. Intracellular nitric oxide (NO) and superoxide $\left(\mathrm{O}_{2}^{-}\right)$levels were determined. Activity of NLRP3 inflammasome in EPCs was assessed by measuring thioredoxin-interacting protein (TXNIP), NLRP3, and caspase-1 expression. Results: Compared with the untreated diabetic mice, wound closure and capillary densities were significantly increased in fenofibrate treated group. Fenofibrate treatment restored EPC function, increased NO production, and decreased $\mathrm{O}_{2}$ - level in EPCs of diabetic mice. Furthermore, fenofibrate deregulated the activity of NLRP3 inflammasome by reducing TXNIP, NLRP3 and caspase-1 expression in EPCs of diabetic mice. In vitro, fenofibrate prevented high glucose induced EPC dysfunction, deregulated NLRP3 inflammasome activity. In addition, fenofibrate inhibited IL-1 $\beta$ expression caused by combination use of high glucose and lipopolysaccharide. Conclusion: Fenofibrate can accelerate wound healing in diabetic mice, which at least in part was mediated by improving the impaired EPC function via a NLRP3 inflammasome pathway, suggesting the significance of PPAR $\alpha$ agonists in the treatment of diabetes.

Y. Deng and X. Han contributed equally to this work.
\end{abstract}

Guojun Jiang, and Feng Han
Department of Pharmacy, Zhejiang Xiaoshan Hospital, Institute of Pharmacology and Toxicology, Zhejiang University, Zhejiang, China;

Tel.+86-571-83865516, E-Mail jguojun999@163.com/changhuahan@zju.edu.cn

\section{KARGER}




\section{Cellular Physiology Cell Physiol Biochem 2017;42:2255-2266 and Biochemistry Publisher $\begin{aligned} & \text { DOI: 10.1159/000479999 } \\ & \begin{array}{l}\text { (c) } 2017 \text { The Author(s). Published by S. Karger AG, Basel } \\ \text { www.karger.com/cpb }\end{array}\end{aligned}$ \\ Deng et al.: PPAR $\alpha$ Agonist and NLRP3 Inflammasome}

\section{Introduction}

Delayed wound healing is a major complication of diabetes mellitus [1]. The lifetime risk of a patient with diabetes developing a foot ulcer reaches as high as $25 \%$, and it is believed that every 30 seconds a lower limb is lost somewhere in the world because of diabetes [2]. Angiogenesis plays an important role in skin maintenance and repair, depending on various kinds of cell participation and coordination, including endothelial precursor cells (EPCs) and endothelial cells (ECs) [3].

EPCs, a group of multi-progenitor cells, has features of self-renewal, and is able to differentiate into ECs $[4,5]$. It was demonstrated that EPCs could be recruited to arterial injury sites and contribute to angiogenesis [6,7]. However, evidences show that the number of circulating EPCs is reduced and their function is impaired in patients with cardiovascular risk factors, including diabetes $[8,9]$. A negative correlation between EPCs and intracellular reactive oxygen species (ROS) production has been proposed [10].Our previous study showed that dysfunction of EPCs retarded angiogenesis in diabetic mice [11].

The NLRP3 inflammasome, being composed of the adaptor protein apoptosis-associated specklike protein (ASC); the proinflammatory caspase, caspase-1; and NLRP3, can be activated by ROS via the ROS-sensitive thioredoxin-interacting protein (TXNIP) protein [12]. The assembly of the inflammasomes results in rapid activation of caspase-1, the enzyme responsible for generating the active forms of IL-1 $\beta[13,14]$, which contributes to EPC dysfunction [15]. While inhibiting the central inflammasome enzyme caspase-1 improves the ability of EPCs to differentiate into mature ECs.

Fenofibrate, a peroxisome proliferator-activated receptor $\alpha$ (PPAR $\alpha)$ agonist [16], clinically available for more than 30 years in the treatment of dyslipidemia, is particularly effective in improving the lipid profile in hypertriglyceridemia and low HDL syndromes $[17,18]$. The ACCORD (Action to Control Cardiovascular Risk in Diabetes) study supports the addition of fenofibrate to a statin for treating patients of dyslipidemia with type 2 diabetes [19]. Treatment with fenofibrate was believed to reduce the risk of amputations, particularly minor amputations without known large-vessel diseases [20], through nonlipid mechanisms. However, mechanisms about fenofibrate on improving micro-vascular complications in hyperglycemia remain unclear. With a mice model of diabetes induced by streptozotocin (STZ), in this work we tested our hypothesis that fenofibrate could accelerate wound healing by improving impaired EPCs function via inhibiting NLRP3 inflammasome.

\section{Materials and Methods}

\section{Animals}

Male C57BL/6J mice (6-8 weeks old, weighing 18-22 g) were purchased from the Sino-British SIPPR/ BK Laboratory Animal Ltd (Shanghai, China), and housed in controlled conditions (temperature: $21 \pm 2^{\circ} \mathrm{C}$ and lighting: 8:00-20:00), with food and water ad libitum. Animals were used in accordance with our institutional guidelines for animal care and the Guide for Care and Use of Laboratory Animals published by the US National Institutes of Health.

\section{Experimental protocols}

Mice were treated with streptozotocin (STZ; 60mg/kg/d x 5d, i.p.; Amresco, Solon, Ohio) to induce diabetes [21]. Random glucose levels was measured by blood glucose monitoring system (Maochang, Taibei, China) on day 20 after STZ injection, and only mice with blood glucose concentrations $\geq 250 \mathrm{mg} / \mathrm{dL}$ were used in the study. Mice served as control were injected with citrate buffer. Three groups were designed: Control, STZ-induced diabetic mice, STZ-induced diabetic mice treated with fenofibrate (FF; Sigma-Aldrich, St. Louis, M0; $100 \mathrm{mg} / \mathrm{kg} /$ day x 14d, i.g.) [22, 23]. Then mice were used for wound closure experiment, or anesthetized to harvest bone marrow to isolate EPCs.

Measurement of wound closure and angiogenesis

Mice were anesthetized with isoflurane prior to the wound-creating surgery. A 6-mm-diameter fullthickness skin wound was made on the dorsal skin with a biopsy punch (Acuderm Inc., Fort Lauderdale, FL). 


\section{Cellular Physiology Cell Physiol Biochem 2017;42:2255-2266

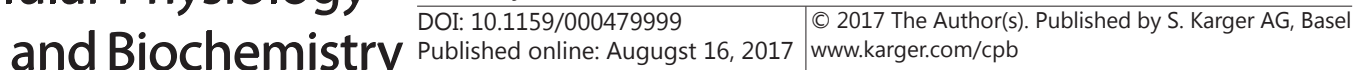 \\ Published onlıne: Augugst 16, 2017 whw}

Wound was dressed with Tegaderm (Nexcare, 3M) and the size of each wound was measured every 2 days with a digital photographs [24]. The wound areas were calculated with Image-Pro Plus software (Media Cybernetics, Silver Spring, MD), and the values were normalized to the initial area of the respective wound.

Skin at the wounded area was collected from mice on day 3, 6, and 9. Wound samples were fixed with 4\% paraformaldehyde (Sigma-Aldrich), then embedded in paraffin, and sectioned at 4- $\mu$ m intervals. After deparaffinization and rehydration, slides were blocked with serum (Vector Laboratories, Burlingame, CA) for $30 \mathrm{~min}$, incubated with an anti-CD31 antibody $(10 \mu \mathrm{g} / \mathrm{ml}, 1: 50$; BD Bioscience, San Jose, CA) for $60 \mathrm{~min}$ at room temperature, and further incubated with Vectastain Elite ABC Reagent (Vector Laboratories, Burlingame, CA) for $30 \mathrm{~min}$ and Nova Red (Vector Laboratories, Burlingame, CA) for 15 min. Slides were counterstained with Hematoxylin (VWR Scientific, Radnor, PA) for $10 \mathrm{~s}$ followed by differentiating in 1\% glacial acetic acid, and rinsing in running tap water. Two slides from each mouse were examined; for each slide, 5 high-power fields (200x) were checked. Capillaries were recognized as tubular structures positive for CD31, and capillary density in the healing wounds was quantified.

\section{Quantification of circulating EPCS}

Circulating EPCs were isolated according to the methods of our previously published papers [11, 25]. Peripheral blood about $0.7 \mathrm{ml}$ was harvested from anesthetized mice and then kept in cool heparin anticoagulant tube. Mononuclear cells were isolated from blood with Histopaque 1083 (Sigma, St. Louis, MO, USA) density gradient centrifugation (3000 rpm) for 25 minutes. After washing and suspension, samples were stained with FITC-conjugated Sca- $1\left(2 \mu \mathrm{g} / 10^{6}\right.$ cells, BD, San Jose, CA, USA) and PE-conjugated Flk$1\left(2 \mu \mathrm{g} / 10^{6}\right.$ cells, BD, San Jose, CA, USA) for 1 hour at $4^{\circ} \mathrm{C}$. Quantification of Sca-1/Flk- 1 doublepositive cells was performed with a BD FACSCalibur Flow cytometer. A non-stained sample was used to set up a threshold, and the isotype specific conjugated anti-IgG was used as a negative control $[11,25]$.

\section{Tube formation and migration assay}

Mouse bone marrow-derived EPCs were isolated, cultured and identified according to the method described previously [26]. The angiogenic capacity of EPCs was determined by Matrigel tube formation assay. Briefly, $50 \mu \mathrm{l}$ /well growth factor-induced Matrigel Matrix (BD Biosciences, Bedford, MA) was placed in the 96-well cell culture plate, then $5 \times 10^{4}$ cells were plated in each well. After $6 \mathrm{~h}$ of incubation, images of tube morphology were taken by inverted microscope (Leica Microsystems Inc., Buffalo Grove, IL), and tubes number were counted at 5 random low-power fields (x50 magnification) per sample.

EPCs migratory capacity was investigated using the modified Boyden chamber assay [25]. Explained briefly, $5 \times 10^{4}$ EPCs were placed in the upper chambers of 24-well Transwell plates per well (Corning Transwell, Lowell, MA) with polycarbonate membrane (8- $\mu$ m pores) that contained serum-free endothelial growth medium; VEGF (50 ng/ml) was added to medium placed in the lower chambers. After $24 \mathrm{~h}$ of incubation at $37^{\circ} \mathrm{C}$ and $5 \% \mathrm{CO}_{2}$, the membrane was washed with PBS, fixed with $2 \%$ paraformaldehyde, and stained by Hoechst $3325810 \mu \mathrm{g} / \mathrm{ml}$ (Sigma-Aldrich, St. Louis, MO). The number of cells on the lower side of the membrane was counted at 5 random low-power $(x 50)$ microscopic fields each sample.

\section{Intracellular superoxide measurement}

Intracellular $\mathrm{O}_{2}^{-}$level was determined using the membrane-permeable dye dihydroethidium (DHE) (Invitrogen, Carlsbad, CA), which is oxidized to ethidium bromide in the presence of $\mathrm{O}_{2}^{-}$[27]. After seven days of cultivation, bone marrow-derived EPCs were harvested using $0.125 \%$ trypsin, and then incubated with DHE $\left(10^{-6} \mathrm{~mol} / \mathrm{L}\right)$ for 30 minutes at $37^{\circ} \mathrm{C}$ in the dark. After incubation, cells were washed with PBS ( $\mathrm{pH}$ 7.4) to remove excess probe and re-suspended in $200 \mu \mathrm{l} \%$ paraformaldehyde. The DHE fluorescence intensity in cells was determined by flow cytometry.

\section{Intracellular nitric oxide measurement}

Intracellular NO levels were determined by flow cytometry assay using the membrane-permeable probes 4-amino-5-methylamine-2', 7'-difluorofluorescein (DAF-FM) diacetate (Invitrogen, Carlsbad, CA) [27]. After seven days of cultivation, bone marrow-derived EPCs were harvested using $0.125 \%$ trypsin, and then incubated with DAF-FM diacetate $\left(10^{-6} \mathrm{~mol} / \mathrm{L}\right)$ for 30 minutes at $37^{\circ} \mathrm{C}$ and an additional 30 minutes at room temperature in the dark to allow complete deesterification of the intracellular diacetates. After incubation, cells were washed with PBS twice and re-suspended in $200 \mu \mathrm{l} 2 \%$ paraformaldehyde before their analysis with a FACS Calibur.

\section{KARGER}




\section{Cellular Physiology Cell Physiol Biochem 2017;42:2255-2266 \begin{tabular}{ll|l} 
and Biochemistry Published online: Augugst 16, 2017 & $\begin{array}{l}\text { (c) } 2017 \text { The Author(s). Published by S. Karger AG, Basel } \\
\text { www.karger.com/cpb }\end{array}$ \\
\hline
\end{tabular} \\ Deng et al.: PPAR $\alpha$ Agonist and NLRP3 Inflammasome}

Western blot analysis for TXNIP, NLRP3, and caspase-1

Bone marrow-derived EPCs were lysed, centrifuged at $12,000 \mathrm{~g}$ at $4^{\circ} \mathrm{C}$ for $15 \mathrm{~min}$, and the supernatant was obtained. We used BCA (Thermo, Rockford, USA) assay to determine the concentration of protein [28]. Samples containing equal amounts of protein were run on 10-15\% SDS-PAGE. The proteins were electrotransferred to nitrocellulose filter membranes. The unbound sites in the protein membranes were incubated in PBS containing 5\% non-fat dry milk for $4 \mathrm{~h}$ at $25^{\circ} \mathrm{C}$. After washing, the blots were incubated overnight at $4^{\circ} \mathrm{C}$ with primary antibodies, and then incubated with secondary antibodies for 30 min at $25^{\circ} \mathrm{C}$ in dark. Primary antibodies used included mouse anti-TXNIP antibody (1:500; International Co., Woburn, MA), rabbit anti-NLRP3 antibody (1:1000; Abcam, Burlingame, CA), rabbit anti-caspase-1 antibody(1:200; Santa Cruz Biotechnology, Santa Cruz, CA), mouse anti-GAPDH (1:1000; Calbiochem, San Diego, CA) and mouse anti-actin (1:1000; Calbiochem, San Diego, CA). Secondary antibodies used included IRDye 800-conjugated anti-mouse antibody (1:5000; Rockland Immunochemical, Inc, Gilberts-ville, PA), and Alexa Fluor 680 goat anti-rabbit IgG antibody (1:5000; Invitrogen, Carlsbad, CA). The images were visualized using Odyssey infrared imaging system (Li-Cor Bioscience, Lincoln, NE), and the bands were quantified by Quantity One (Bio-Rad, Hercules, CA, USA).

\section{In Vitro study}

EPCs were obtained from male C57BL/6 mice. After 7 days of culturing, medium were replaced with high glucose $(33 \mathrm{mM})$ medium [29] or high glucose medium containing fenofibrate $(1,5$ or $10 \mu \mathrm{M}$ [30]) for $24 \mathrm{~h}$, or fenofibrate $(5 \mu \mathrm{M})$ together with glibenclamide (a NLRP3 inflammasome inhibitor; $5 \mu \mathrm{M}$ [31]) and LPS (Sigma-Aldrich, St. Louis, MO, $1 \mu \mathrm{g} / \mathrm{ml}$ [32]) for 24h. Effects of fenofibrate on high glucose induced EPCs dysfunction were assessed by both the migration and tube formation capacities, and by intracellular $\mathrm{NO}$ and $\mathrm{O}_{2}^{-}$levels. Activity of NLRP3 inflammasome in EPCs was assessed by measuring TXNIP, NLRP3, and caspase- 1 expression. The supernatants were collected, and IL-1 $\beta$ was measured with commercially available ELISA kits (R\&D Systems, Minneapolis, MN, USA) [33].

\section{Statistical analysis}

Data were expressed as mean \pm SEM. Results were analyzed by 1-way ANOVA with Newman-Keuls multiple comparison test or Krukal-wallis test. A probability value of $<0.05$ was considered statistically significant.

\section{Results}

Influences of fenofibrate on body weight and metabolic profiles in diabetic mice

Fifteen days after a 5-day low-dose STZ injection, the body weight was markedly decreased when compared with the control (19.7 \pm 0.5 vs $24.5 \pm 0.4 \mathrm{~g}, \mathrm{P}<0.01)$, while blood glucose level in STZ-induced diabetic mice was significantly increased (538 \pm 40 vs $123 \pm 3$ $\mathrm{mg} / \mathrm{dL}, \mathrm{P}<0.01$ ). Two weeks treatment with fenofibrate did not modify the blood glucose level and body weight in STZ-induced diabetic mice. It was also found that serum triglyceride (TG) level was significantly increased when compared with the control $(2.42 \pm 0.31$ vs $1.52 \pm$ $0.11 \mathrm{mmol} / \mathrm{L}, \mathrm{P}<0.05)$, while high-density lipoprotein cholesterol (HDL-C) was not changed in these diabetic mice. Fenofibrate treatment significantly decreased the level of TG $1.50 \pm$ 0.22 vs $2.42 \pm 0.31 \mathrm{mmol} / \mathrm{L}, \mathrm{P}<0.05)$ and increased the level of HDL-C $(2.76 \pm 0.22$ vs 2.23 $\pm 0.14 \mathrm{mmol} / \mathrm{L}, \mathrm{P}<0.05$ ).

\section{Fenofibrate accelerated wound closure and angiogenesis in diabetic mice}

As shown in Fig. 1, compared with the control, the wound closure rate was significantly delayed in STZ-induced diabetic. The wound healing rate in diabetic mice treated with fenofibrate was greater than that in the untreated diabetic mice $(P<0.05$, Fig. $1 \mathrm{~A}$ and $1 \mathrm{~B})$. These suggest that fenofibrate could significantly improve wound healing in diabetic mice.

On day 3, capillary formation was significantly worse in STZ-induced diabetic compared with control mice $(P<0.01$, Fig. $1 \mathrm{C}$ and 1D) and fenofibrate did not augment capillary formation. On day 6 and 9, diabetic mice displayed significantly less capillary formation compared with control mice $(P<0.01$, Fig. $1 \mathrm{C}$ and 1D). However, 
Fig. 1. Fenofibrate (FF) accelerated wound healing and enhanced wound angiogenesis in streptozotocin-induced diabetic mice (STZ). Six-mm diameter wound was made by punch biopsy, wound closure was measured every other day until day 12. (A) Representative photographs of wound healing. (B) Fenofibrate accelerated the percentage of wound closure in STZinduced diabetic mice as compared with the untreated diabetic ones. Wound angiogenesis was measured on day 3, 6 and 9. (C) Quantitative analysis of capillaries per high-power field (hpf) showed that wound capillaries in FF treated diabetic mice were increased on day 6 and 9 when compared with the untreated

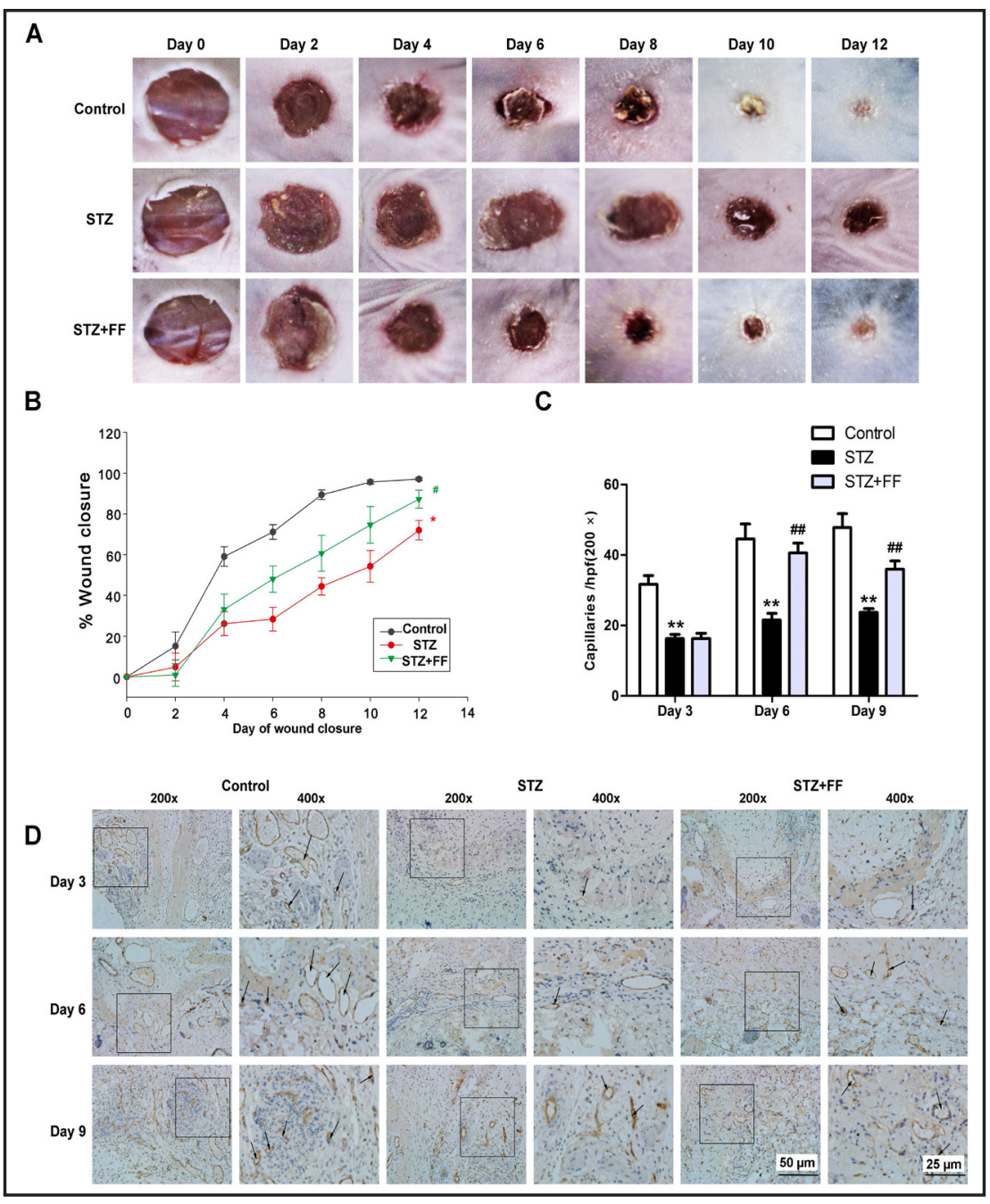
diabetic ones. (D) Representative photomicrographs of CD31 staining; black arrows point to CD31-positive capillaries; boxed regions $(200 \times)$ are shown at higher magnification $(400 \times)$ to the right. Values are mean \pm SEM. $\mathrm{n}=9$-15 per group. ${ }^{*} \mathrm{P}<0.05,{ }^{* *} \mathrm{P}<0.01$ vs Control; ${ }^{~} \mathrm{P}<0.05$, ${ }^{\# \#} \mathrm{P}<0.01$ vs STZ.

fenofibrate treatment significantly increased the capillary densities in diabetic mice when compared with the untreated diabetic ones $(P<0.01$, Fig. $1 \mathrm{C}$ and $1 \mathrm{D})$. These data demonstrate that fenofibrate is effective to enhance angiogenesis in diabetic mice.

\section{Fenofibrate improved EPC function of diabetic mice}

To understand whether the accelerated wound healing in diabetic mice were potentially mediated by the increase of EPC number and the improvement of EPC function, the number of circulating EPCs, and the capacities of tube formation and migration of EPCs were assessed. As shown in Fig. 2A and 2B, the number of circulating EPCs was significantly lower in diabetic mice compared with controls $(1.18 \pm 0.26$ vs $2.85 \pm 0.19 \%, P<0.01)$, and fenofibrate treatment prevented this reduction in diabetic mice $(2.17 \pm 0.24 \%, P<0.01)$. Similarly, it was found that EPCs from STZ-induced diabetic mice showed significantly decreased cell tube formation ( $55 \pm 2$ vs $88 \pm 2, P<0.01)$ and migration $(52 \pm 6$ vs $100 \pm 9, P<0.01)$ capacities as compared with the control group. Fenofibrate treatment significantly increased both the capacities of tube formation ( $75 \pm 2$ vs $55 \pm 2, P<0.01)$ and migration $(108 \pm 9$ vs $52 \pm 6, P$ $<0.01$ ) in STZ-induced diabetic mice when compared with the untreated diabetic ones (Fig. 2C-2F). 
Fig. 2. Fenofibrate improved EPCs functions of STZinduced diabetic mice. (A and B) Fenofibrate increased the circulating EPCs number of diabetic mice. (C and D) Fenofibrate enhanced the tube formation capacity of EPCs in diabetic mice. (E and F) Fenofibrate enhanced the migratory capacity of EPCs in diabetic mice. Values are mean \pm SEM. $n=5-7$ per group. ${ }^{*} \mathrm{P}<0.01$ vs Control; ${ }^{\#} \mathrm{P}<0.01$ vs STZ.

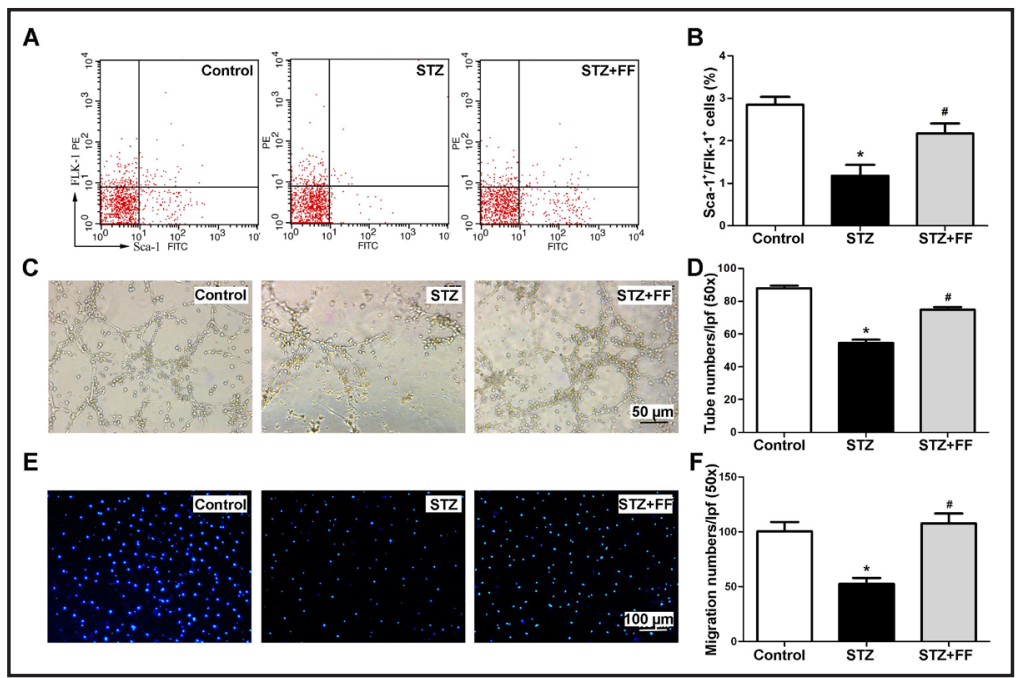

Fig. 3. Fenofibrate decreased reactive oxygen species (ROS) expression in EPCs of STZinduced diabetic mice. (A and C) Intracellular DHE fluorescence of EPCs from each group was assessed by flow cytometry. (B and D) Intracellular DAF fluorescence of EPCs from each group was assessed by flow cytometry. Values are mean \pm SEM. $\mathrm{n}=7-8$ per group. ${ }^{*} \mathrm{P}<0.05$ vs Control; ${ }^{\#} \mathrm{P}<0.05$, ${ }^{\# \#} \mathrm{P}<0.01$ vs STZ.

Fenofibrate reduced ROS production in EPCs of diabetic mice

The $\mathrm{O}_{2}$ - level in EPCs from diabetic mice was significantly elevated $(1.36 \pm$ 0.05 vs $1.00 \pm 0.03, P<0.05$ ), fenofibrate treatment for diabetic mice prevented this elevation when compared with the untreated ones $(1.05 \pm 0.15$ vs $1.36 \pm 0.05$, $P<0.05$; Fig. 3A and 3C). On the contrary,

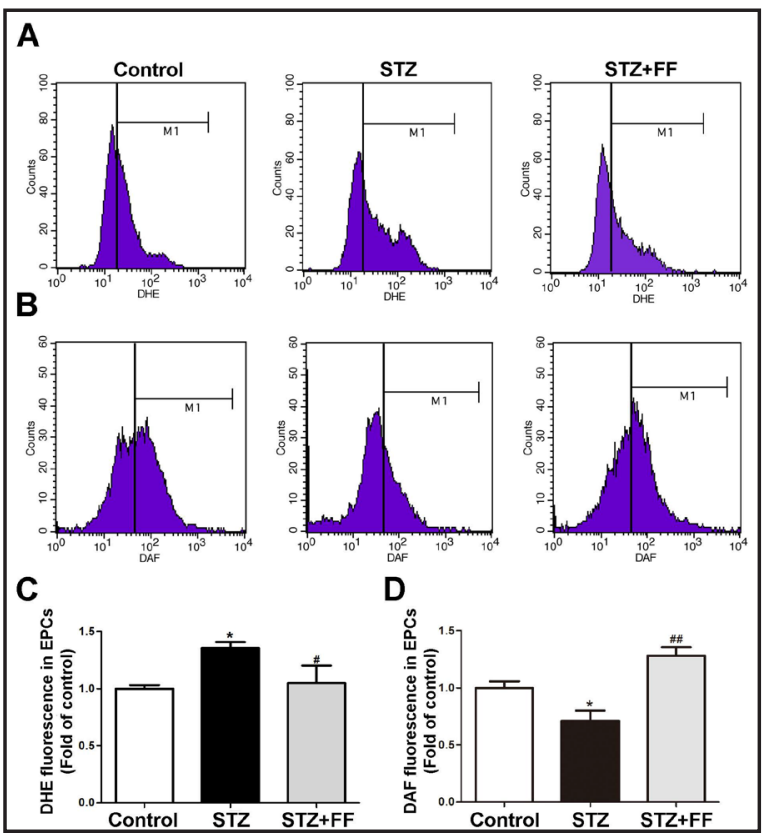
the NO level in EPCs was significantly reduced in diabetic mice when compared with the control $(0.71 \pm 0.09$ vs $1.00 \pm 0.06, P<$ $0.05)$, fenofibrate treatment for diabetic mice increased the NO level when compared with the untreated ones $(1.28 \pm 0.08$ vs $0.71 \pm 0.09, P<0.01$; Fig. $3 \mathrm{~B}$ and $3 \mathrm{D})$.

\section{Fenofibrate inhibited NLRP3 inflammasome in EPCs of diabetic mice}

As NLRP3 inflammasome can be activated via the ROS-sensitive TXNIP protein, which subsequently stimulated the development of caspases-1 [12, 34]. Thus TXNIP, NLRP3, caspase- 1 were measured. It was found that fenofibrate treatment for diabetic mice significantly reversed TXNIP $(0.71 \pm 0.08$ vs $1.25 \pm 0.05, P<0.01$; Fig. 4A), NLRP3 $(0.55 \pm 0.07$ vs $1.18 \pm 0.04, P<0.01$; Fig. 4B), caspases-1 (1.11 \pm 0.12 vs $1.53 \pm 0.15$; Fig. 4C) expression when compared with the untreated ones. These suggest that fenofibrate inhibited NLRP3 inflammasome activity in EPCs of diabetic mice.

\section{Fenofibrate attenuated high glucose-induced EPCs dysfunction}

To investigate whether results from the animal study could be related to the increased glucose concentration in mice, high glucose was used to induce EPCs dysfunction in vitro. 
Fig. 4. Fenofibrate decreased NLRP3 inflammasome expression in EPCs of STZ-induced diabetic mice. Western blot analysis was used to determine changes of TXNIP, NLRP3 and caspase- 1 expression in EPCs of STZ-induced diabetic mice with or without fenofibrate treatment. (A) TXNIP expression. (B) NALP3 expression. (C) caspase-1 expression. Values are mean \pm SEM. $n=5-8$ per group. ${ }^{*} \mathrm{P}<0.05$ vs Control; ${ }^{\# \#} \mathrm{P}<0.01$ vs STZ.
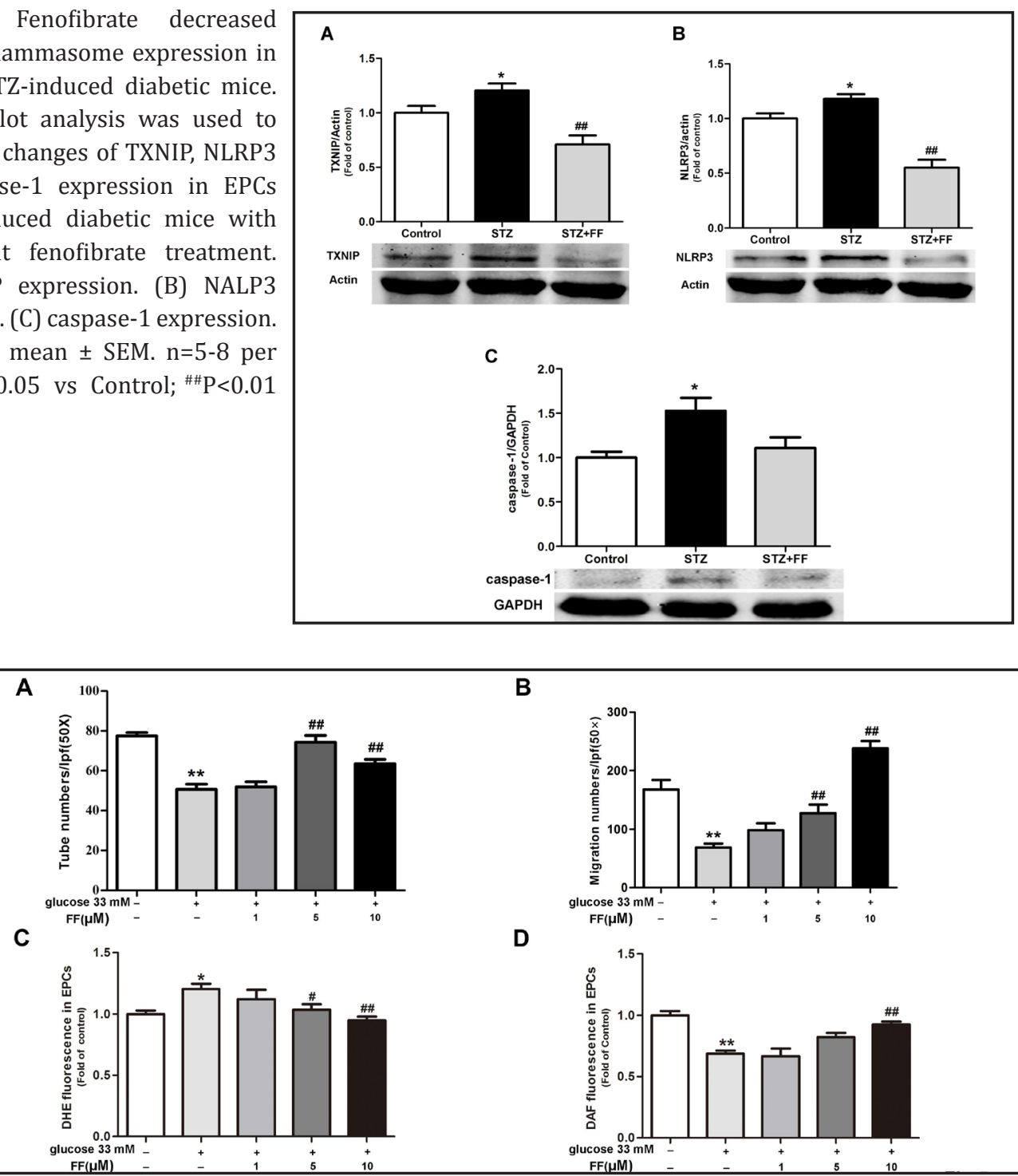

B

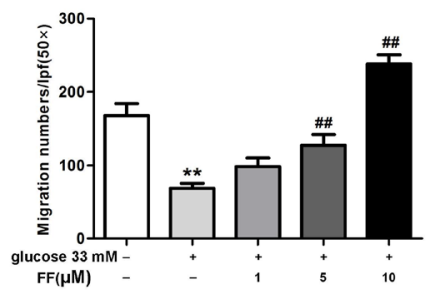

D

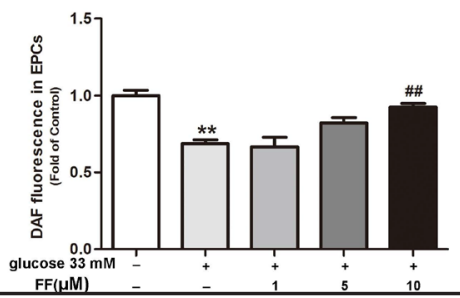

Fig. 5. Fenofibrate improved impaired EPCs functions and decreased ROS expression in EPCs induced by high glucose (HG). Ability of EPCs functions were assessed after $24 \mathrm{~h}$ incubation with either high glucose medium or high glucose medium together with fenofibrate(1, or 5, or $10 \mu \mathrm{M})$. Measurement of tube formation ability (A), migratory capacity (B). (C) Intracellular DHE fluorescence of EPCs from each group was assessed by flow cytometry. (D) Intracellular DAF fluorescence of EPCs from each group was assessed by flow cytometry. Values are mean \pm SEM. $\mathrm{n}=5-8$ per group. ${ }^{*} \mathrm{P}<0.05,{ }^{* *} \mathrm{P}<0.01$ vs Control; ${ }^{\#} \mathrm{P}<0.05$, ${ }^{\# \#} \mathrm{P}<0.01$ vs HG.

High glucose treatment impaired both the capacity of tube formation and migration of cultured EPCs. Fenofibrate $(1,5$ and $10 \mu \mathrm{M})$ treatment improved impaired EPC function caused by high glucose (Fig. 5A and 5B). In addition, high glucose resulted in increased $\mathrm{O}_{2}^{-}$ formation and decreased NO production as compared with the control, while fenofibrate treatment reversed these changes (Fig. 5C and 5D).

\section{Fenofibrate inhibited NLRP3 inflammasome activity and IL-1 $\beta$ expression}

Expression of TXNIP, NLRP3 and caspases-1 were significantly higher in high glucose treated EPCs, fenofibrate treatment markedly reduced either TXNIP, or NLRP3 or caspases-1 caused by high glucose in vitro (Fig. 6A-6C). It is known that caspase- 1 is responsible for 
Fig. 6. Fenofibrate decreased NLRP3 inflammasome expression in EPCs induced by high glucose. Western blot analysis was used to determine changes of TXNIP, NLRP3 and caspase-1expression in EPCs induced by high glucose with or without fenofibrate treatment.

(A) TXNIP expression.

(B)

NALP3 expression. (C) caspase-1 expression. Values are mean \pm SEM. $\mathrm{n}=6$-8 per group. ${ }^{*} \mathrm{P}<0.05,{ }^{* *} \mathrm{P}<0.01$ vs Control; $\mathrm{P}<0.05$, \#\# $\mathrm{P}<0.01$ vs HG.

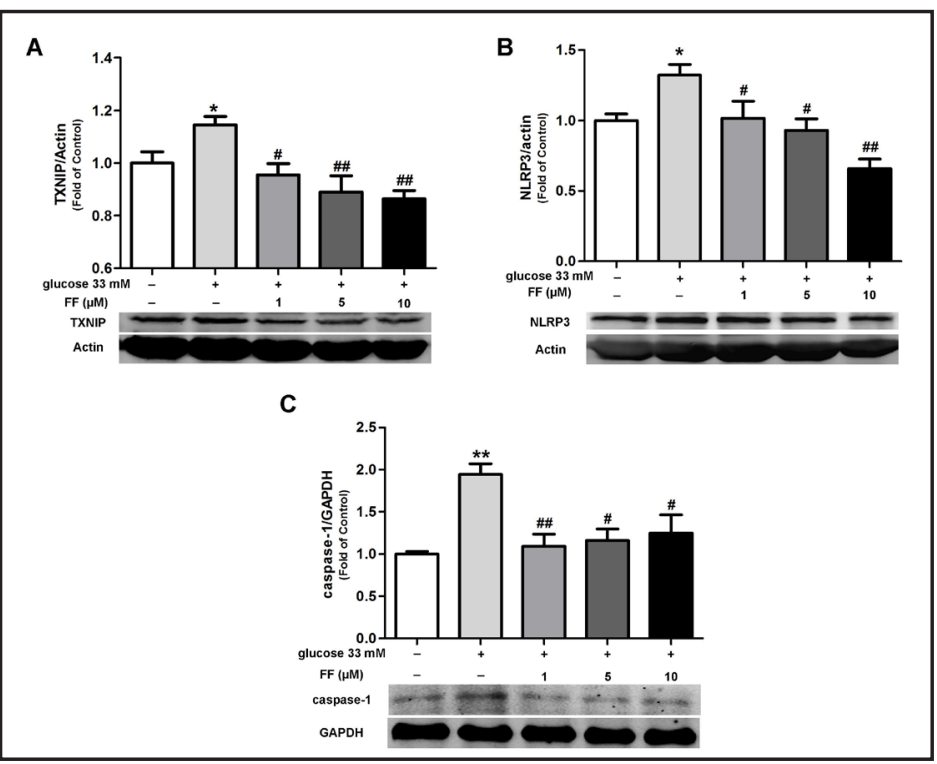

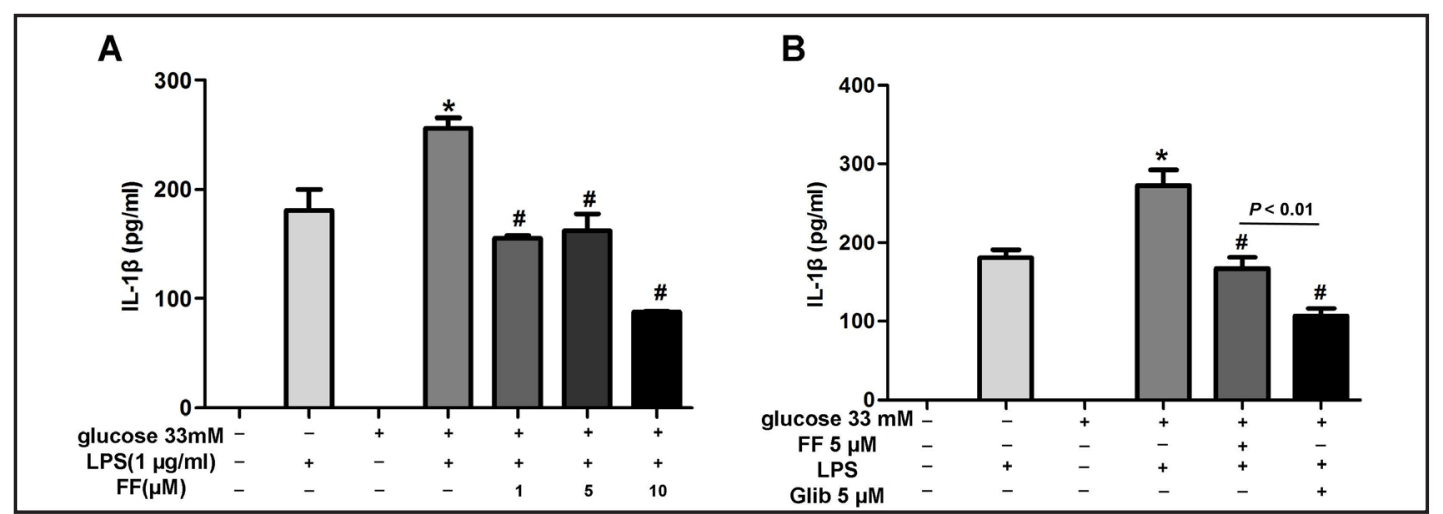

Fig. 7. Effects of fenofibratae and glyburide on EPCs IL-1 $\beta$ level. (A) IL-1 $\beta$ level of EPCs was measured by ELISA. (B) Determination of IL-1 $\beta$ level after incubation with NALP3 nonspecific inhibitor glyburide. Values are mean \pm SEM. $n=6$-9 per group. ${ }^{*} \mathrm{P}<0.01$ vs Control; ${ }^{\#} \mathrm{P}<0.01$ vs $\mathrm{HG}$.

generation of the active forms of IL- $1 \beta$ from pro-IL-1 $\beta$. Thus lipopolysaccharide (LPS, $1 \mu \mathrm{g} / \mathrm{ml}[35])$ was used to induce pro-IL-1 $\beta$. Though high glucose alone did not induce IL$1 \beta$ expression, it was found that IL- $1 \beta$ was increased in high glucose and LPS treated EPCs compared with the LPS treated one. Fenofibrate $(1,5$ and $10 \mu \mathrm{M})$ treatment decreased IL-1 $\beta$ expression caused by high glucose and LPS (Fig. 7A). Glibenclamide is a NLRP3 inflammasome inhibitor [31]. In this work, we found that fenofibrate treatment decreased the IL-1 $\beta$ level in EPCs similar to the treatment of glibenclamide (Fig. 7B).

\section{Discussion}

The major findings in this study are that (a) fenofibrate treatment could accelerate wound healing in STZ-induced diabetic mice; (b) fenofibrate recovered the impaired EPCs capacities, inhibited NLRP3 inflammasome activity in EPCs of diabetic mice; (c) In vitro, fenofibrate reversed high glucose-impaired EPCs functions, inhibited NLRP3 inflammasome activity induced by high glucose, and IL- $1 \beta$ expression induced by combination of high 
glucose and LPS in EPCs. Therefore, we for the first time demonstrated that fenofibrate could improve chronic hyperglycemia impaired EPC functions via a NLRP3 inflammasome pathway in diabetic mice.

In patients with diabetes, impaired angiogenesis reduced peripheral blood flow, which can retard wound healing and lead to the development of foot ulcers [36]. Ulcer wounds with impaired healing and repeated infection result in the risk of lower limb amputation [1]. Studies demonstrated fenofibrate protected against diabetic microvascular-associated complications in type 2 diabetic patients. The ACCORD study supports the idea that adding fenofibrate to a statin may benefit patients of dyslipidemia with type 2 diabetes [19] , and long term use of fenofibrate in severely burned patients improved wound healing [37]. Treatment with fenofibrate was believed to reduce the risk of amputations, particularly minor amputations without known large-vessel diseases [20]. In this work, with STZ-induced diabetic mice, we found that fenofibrate treatment did increase the capillary densities and accelerated wound healing.

Investigators have long focused on the detrimental effects of high glucose on diabetic wound healing, recent work suggested that EPC dysfunction under diabetic condition had a secondary effect on diabetic wound healing [38]. EPCs, possessing the features of self-renewal, is able to differentiate into endothelial cells [4]. The capability of EPCs of being recruited to arterial injury sites and contributing to vasculogenesis has been demonstrated [6]. Inadequate EPCs proliferation, mobilization, and trafficking played a role in delayed diabetic wound healing [38]. Studies indicate that EPCs function is impaired in diabetic patients and the number of circulating EPCs is significantly reduced both in type 1 [39] and type 2 [10] diabetic patients. These suggest that it might be clinically significance to increase circulating EPCs number and/or to improve EPCs functions with certain specific drugs in the treatment for diabetes, especially for diabetic vascular complications. Compared with the control, we found that circulating EPCs was significantly increased in STZ-induced diabetic mice after fenofibrate treatment, and the migration and tube formation capacities of EPCs was markedly augmented after fenofibrate administration both in vivo and in vitro. Thus, we postulated that the effect of fenofibrate in accelerating wound healing under diabetic condition was possibly related to recover impaired EPCs function and to increase circulating EPCs number.

A negative correlation between the angiogenesis and intracellular ROS production has been proposed $[10,40]$. Diabetes mellitus enhances the ROS, thus resulting in diminished NO bioavailability. Increased oxidative stress in the vasculature is a major contributor of endothelial dysfunction mediated by the $\mathrm{O}_{2}^{-}$production [41] and impairment of NO bioavailability in the vascular wall in diabetes mellitus [42]. In this study we found that fenofibrate decreased the $\mathrm{O}_{2}$ - production and increased the NO level in EPCs both in vivo and in vitro.

TXNIP is a pivotal modulator in high glucose-induced inflammation, $\mathrm{O}_{2}-$ production and impairment of NO signaling [43]. Glucose is a potent inducer of TXNIP in pancreatic islets [12]. In this work, we found that TXNIP protein level was increased in EPCs from diabetic mice and in EPCs treated with high glucose, and fenofibrate treatment decreased the TXNIP protein level. TXNIP can directly bind to NLRP3 in a ROS sensitive manner. Previous studies have demonstrated that ROS caused high levels of TXNIP, thus causing NLRP3 activation [44], which subsequently lead to activation of caspase- 1 and forming of IL-1 $\beta$ [12]. It is well accepted that enhanced IL-1 $\beta$ may play a deleterious role in angiogenesis and vascular repairing [13]. In the present study, we found that fenofibrate decreased TXNIP, NLRP3 and caspase- 1 protein levels both in vivo and in vitro. We also found that the level of IL-1 $\beta$ was increased in high glucose and LPS treated EPCs, and fenofibrate treatment prevented the increase of IL-1 $\beta$ expression with a manner similar to glibenclamide (a NLRP3 inhibitor). Thus, we further postulated that fenofibrate could stimulate angiogenesis by deregulating NLRP3 inflammasome activity and inhibiting IL-1 $\beta$ expression in EPCs of diabetic mice. 


\section{Cellular Physiology Cell Physiol Biochem 2017;42:2255-2266 \begin{tabular}{ll|l} 
and Biochemistry & $\begin{array}{l}\text { DOI: 10.1159/000479999 } \\
\text { Published onlıne: Augugst 16, } 2017\end{array}$ & $\begin{array}{l}\text { (c) } 2017 \text { The Author(s). Published by S. Karger AG, Basel } \\
\text { www.karger.com/cpb }\end{array}$ \\
\hline
\end{tabular} \\ Deng et al.: PPAR $\alpha$ Agonist and NLRP3 Inflammasome}

\section{Conclusion}

Fenofibrate could accelerate wound healing in STZ-induced diabetic mice by improving the impaired EPCs function via a NLRP3 inflammasome pathway. These suggest that fibrates, mainly used in the treatment of dyslipidemia, maybe potentially useful in the treatment of diabetes, especially for reducing the risk of amputations in diabetes.

\section{Acknowledgements}

This study was supported by the grants from Natural Science Foundation of Zhejiang (20131813A20, 20130733Q41, 2015KYB331, 20150633B58, 2012C33108, 2012ZDA039, 2013RCB014), Industry-Academia-Research project of Shanghai Committee of Science and Technology (14DZ1930806).

\section{Disclosure Statement}

None.

\section{References}

1 Zhang J, Li L, Li J, Liu Y, Zhang CY, Zhang Y, Zen K: Protein tyrosine phosphatase 1B impairs diabetic wound healing through vascular endothelial growth factor receptor 2 dephosphorylation. Arterioscler Thromb Vasc Biol 2015;35:163-174.

-2 Boulton AJ, Vileikyte L, Ragnarson-Tennvall G, Apelqvist J: The global burden of diabetic foot disease. Lancet 2005; 66:1719-1724.

- 3 Qi W, Yang C, Dai Z, Che D, Feng J, Mao Y, Cheng R, Wang Z, He X, Zhou T, Gu X, Yan L, Yang X, Ma JX, Gao G: High levels of pigment epithelium-derived factor in diabetes impair wound healing through suppression of Wnt signaling. Diabetes 2015;64:1407-1419.

-4 Asahara T, Murohara T, Sullivan A, Silver M, van der Zee R, Li T, Witzenbichler B, Schatteman G, Isner JM: Isolation of putative progenitor endothelial cells for angiogenesis. Science 1997;275: 964-967.

-5 Yang JX, Pan YY, Ge JH, Chen B, Mao W, Qiu YG, Wang XX: Tanshinone II A Attenuates TNF- $\alpha$-Induced Expression of VCAM-1 and ICAM-1 in Endothelial Progenitor Cells by Blocking Activation of NF- $\mathrm{KB}$. Cell Physiol Biochem 2016;40:195-206.

6 Tie L, Chen LY, Chen DD, Xie HH, Channon KM, Chen AF: GTP cyclohydrolase I prevents diabetic-impaired endothelial progenitor cells and wound healing by suppressing oxidative stress/thrombospondin-1. Am J Physiol Endocrinol Metab 2014;306:E1120-1131.

7 Chen X, Chen Q, Wang L, Li G: Ghrelin induces cell migration through GHSR1a-mediated PI3K/Akt/eNOS/ NO signaling pathway in endothelial progenitor cells. Metabolism 2013;62:743-752.

-8 Rosso A, Balsamo A, Gambino R, Dentelli P, Falcioni R, Cassader M, Pegoraro L, Pagano G, Brizzi MF: p53 Mediates the accelerated onset of senescence of endothelial progenitor cells in diabetes. J Biol Chem 2006;281:4339-4347.

-9 Zhou J, Ni X, Huang X, Yao J, He Q Wang K, Duan T: Potential Role of Hyperglycemia in Fetoplacental Endothelial Dysfunction in Gestational Diabetes Mellitus. Cell Physiol Biochem 2016;39:1317-1328.

10 Thum T, Fraccarollo D, Schultheiss M, Froese S, Galuppo P, Widder JD, Tsikas D, Ertl G, Bauersachs J: Endothelial nitric oxide synthase uncoupling impairs endothelial progenitor cell mobilization and function in diabetes. Diabetes 2007;56:666-674.

11 Yu JW, Deng YP, Han X, Ren GF, Cai J, Jiang GJ: Metformin improves the angiogenic functions of endothelial progenitor cells via activating AMPK/eNOS pathway in diabetic mice. Cardiovasc Diabetol 2016;15:88.

12 Schroder K, Zhou R, Tschopp J: The NLRP3 inflammasome: a sensor for metabolic danger. Science 2010;327:296-300. 


\section{Cellular Physiology Cell Physiol Biochem 2017;42:2255-2266 \begin{tabular}{l|l|l} 
DOI: 10.1159/000479999 & $\begin{array}{l}\text { O 2017 The Author(s). Published by S. Karger AG, Basel } \\
\text { www.karger.com/cpb }\end{array}$
\end{tabular} \\ Deng et al.: PPAR $\alpha$ Agonist and NLRP3 Inflammasome}

13 Kahlenberg JM, Thacker SG, Berthier CC, Cohen CD, Kretzler M, Kaplan MJ: Inflammasome activation of IL-18 results in endothelial progenitor cell dysfunction in systemic lupus erythematosus. J Immunol 2011;187:6143-6156.

$>14$ Liu W, Zhang X, Zhao M, Zhang X, Chi J, Liu Y, Lin F, Fu Y, Ma D, Yin X: Activation in M1 but not M2 Macrophages Contributes to Cardiac Remodeling after Myocardial Infarction in Rats: a Critical Role of the Calcium Sensing Receptor/NRLP3 Inflammasome. Cell Physiol Biochem 2015;35:2483-2500.

15 Mao A, Liu C, Guo Y, Su D, Luo T, Fu W, Zhou H, Fang G, Sheng Y: Modulation of the number and functions of endothelial progenitor cells by interleukin $1 \beta$ in the peripheral blood of pigs: involvement of p38 mitogenactivated protein kinase signaling in vitro. J Trauma Acute Care Surg 2012;73:1145-1151.

16 Bhattacharjee S, Das N, Mandala A, Mukhopadhyay S, Roy SS: Fenofibrate Reverses Palmitate Induced Impairment in Glucose Uptake in Skeletal Muscle Cells by Preventing Cytosolic Ceramide Accumulation. Cell Physiol Biochem 2015;37:1315-1328.

17 Chen Y, Hu Y, Lin M, Jenkins AJ, Keech AC, Mott R, Lyons TJ, Ma JX: Therapeutic effects of PPAR $\alpha$ agonists on diabetic retinopathy in type 1 diabetes models. Diabetes 2013;62:261-272.

18 Ferreira AV, Menezes-Garcia Z, Mario EG, Delpuerto HL, Martins AS, Botion LM: Increased expression of oxidative enzymes in adipose tissue following PPAR $\alpha$-activation. Metabolism 2014;63:456-460.

19 Ginsberg HN, Elam MB, Lovato LC, Crouse JR, Leiter LA, Linz P, Friedewald WT, Buse JB, Gerstein HC, Probstfield J, Grimm RH, Ismail-Beigi F, Bigger JT, Goff DC, Cushman WC, Simons-Morton DG, Byington RP: Effects of combination lipid therapy in type 2 diabetes mellitus. N Engl J Med 2010;362:1563-1574.

20 Rajamani K, Colman PG, Li LP, Best JD, Voysey M, D’Emden MC, Laakso M, Baker JR, Keech AC: Effect of fenofibrate on amputation events in people with type 2 diabetes mellitus (FIELD study): a prespecified analysis of a randomised controlled trial. Lancet 2009;373:1780-1788.

-21 Poittevin M, Bonnin P, Pimpie C, Rivière L, Sebrié C, Dohan A, Pocard M, Charriaut-Marlangue C, Kubis N: Diabetic microangiopathy: impact of impaired cerebral vasoreactivity and delayed angiogenesis after permanent middle cerebral artery occlusion on stroke damage and cerebral repair in mice. Diabetes 2015;64:999-1010.

22 Chan SM, Sun RQ, Zeng XY, Choong ZH, Wang H, Watt MJ, Ye JM: Activation of PPAR $\alpha$ ameliorates hepatic insulin resistance and steatosis in high fructose-fed mice despite increased endoplasmic reticulum stress. Diabetes 2013;62:2095-2105.

23 Lebrasseur NK, Duhaney TA, De Silva DS, Cui L, Ip PC, Joseph L, Sam F: Effects of fenofibrate on cardiac remodeling in aldosterone-induced hypertension. Hypertension 2007;50:489-496.

-24 Liu M, Saeki K, Matsunobu T, Okuno T, Koga T, Sugimoto Y, Yokoyama C, Nakamizo S, Kabashima K, Narumiya S, Shimizu T, Yokomizo T: 12-Hydroxyheptadecatrienoic acid promotes epidermal wound healing by accelerating keratinocyte migration via the BLT2 receptor. J Exp Med 2014;211:1063-1078.

-25 Dong XH, Sun X, Jiang GJ, Chen AF, Xie HH: Dietary intake of sugar substitutes aggravates cerebral ischemic injury and impairs endothelial progenitor cells in mice. Stroke 2015;46:1714-1718.

26 Chen JK, Deng YP, Jiang GJ, Liu YZ, Zhao T, Shen FM: Establishment of tube formation assay of bone marrowderived endothelial progenitor cells. CNS Neurosci Ther 2013;19:533-535.

-27 Xie HH, Zhou S, Chen DD, Channon KM, Su DF, Chen AF: GTP cyclohydrolase I/BH4 pathway protects EPCs via suppressing oxidative stress and thrombospondin-1 in salt-sensitive hypertension. Hypertension 2010;56:1137-1144.

28 Liu SY, Zhang YY, Gao Y, Zhang LJ, Chen HY, Zhou Q, Chai ML, Li QY, Jiang H, Yuan B, Dai LS, Zhang JB: MiR-378 Plays an Important Role in the Differentiation of Bovine Preadipocytes. Cell Physiol Biochem 2015;36:1552-1562.

29 Marchetti V, Menghini R, Rizza S, Vivanti A, Feccia T, Lauro D, Fukamizu A, Lauro R, Federici M: Benfotiamine counteracts glucose toxicity effects on endothelial progenitor cell differentiation via Akt/ FoxO signaling. Diabetes 2006;55:2231-2237.

30 Zeng L, Tang W, Yin J, Feng L, Li Y, Yao X, Zhou B: Alisol A 24-Acetate Prevents Hepatic Steatosis and Metabolic Disorders in HepG2 Cells. Cell Physiol Biochem 2016;40:453-464.

31 Lamkanfi M, Mueller JL, Vitari AC, Misaghi S, Fedorova A, Deshayes K, Lee WP, Hoffman HM, Dixit VM: Glyburide inhibits the Cryopyrin/Nalp3 inflammasome. J Cell Biol 2009;187:61-70.

32 Rao TP, Okamoto T, Akita N, Hayashi T, Kato-Yasuda N, Suzuki K: Amla (Emblica officinalis Gaertn.) extract inhibits lipopolysaccharide-induced procoagulant and pro-inflammatory factors in cultured vascular endothelial cells. Br J Nutr 2013;110:2201-2206. 


\section{Cellular Physiology Cell Physiol Biochem 2017;42:2255-2266 \begin{tabular}{l|l|l} 
DOI: 10.1159/000479999 & $\begin{array}{l}\text { O 2017 The Author(s). Published by S. Karger AG, Basel } \\
\text { www.karger.com/cpb }\end{array}$ \\
\hline
\end{tabular} \\ Deng et al.: PPAR $\alpha$ Agonist and NLRP3 Inflammasome}

33 Cai J, Lu S, Yao Z, Deng YP, Zhang LD, Yu JW, Ren GF, Shen FM, Jiang GJ: Glibenclamide attenuates myocardial injury by lipopolysaccharides in streptozotocin-induced diabetic mice. Cardiovasc Diabetol 2014;13:106. Martinon F: Signaling by ROS drives inflammasome activation. Eur J Immunol 2010;40:616-619.

-35 Serizawa F, Patterson E, Potter RF, Fraser DD, Cepinskas G: Pretreatment of human cerebrovascular endothelial cells with CO-releasing molecule-3 interferes with JNK/AP-1 signaling and suppresses LPSinduced proadhesive phenotype. Microcirculation 2015;22:28-36.

-36 Forsythe RO, Hinchliffe RJ: Assessment of foot perfusion in patients with a diabetic foot ulcer. Diabetes Metab Res Rev 2016;32:232-238.

-37 Elijah IE, Børsheim E, Maybauer DM, Finnerty CC, Herndon DN, Maybauer MO: Role of the PPAR- $\alpha$ agonist fenofibrate in severe pediatric burn. Burns 2012;38:481-486.

-38 Tanaka R, Vaynrub M, Masuda H, Ito R, Kobori M, Miyasaka M, Mizuno H, Warren SM, Asahara T: Qualitycontrol culture system restores diabetic endothelial progenitor cell vasculogenesis and accelerates wound closure. Diabetes 2013;62:3207-3217.

-39 Loomans CJ, de Koning EJ, Staal FJ, Rookmaaker MB, Verseyden C, de Boer HC, Verhaar MC, Braam B, Rabelink TJ, van Zonneveld AJ: Endothelial progenitor cell dysfunction: a novel concept in the pathogenesis of vascular complications of type 1 diabetes. Diabetes 2004;53:195-199.

40 Sun L, Yuan Q, Xu T, Yao L, Feng J, Ma J, Wang L, Lu C, Wang D: Pioglitazone, a Peroxisome ProliferatorActivated Receptor x03B3; Agonist, Ameliorates Chronic Kidney Disease by Enhancing Antioxidative Capacity and Attenuating Angiogenesis in the Kidney of a 5/6 Nephrectomized Rat Model. Cell Physiol Biochem 2016;38:1831-1840.

41 Tao RR, Wang H, Hong LJ, Huang JY, Lu YM, Liao MH, Ye WF, Lu NN, Zhu DY, Huang Q Fukunaga K, Lou YJ, Shoji I, Wilcox CS, Lai EY, Han F: Nitrosative stress induces peroxiredoxin 1 ubiquitination during ischemic insult via E6AP activation in endothelial cells both in vitro and in vivo. Antioxid Redox Signal 2014;21:1-16.

-42 Tousoulis D, Papageorgiou N, Androulakis E, Siasos G, Latsios G, Tentolouris K, Stefanadis C: Diabetes mellitus-associated vascular impairment: novel circulating biomarkers and therapeutic approaches. J Am Coll Cardiol 2013;62:667-676.

-43 Jung H, Kim MJ, Kim DO, Kim WS, Yoon SJ, Park YJ, Yoon SR, Kim TD, Suh HW, Yun S, Min JK, Lee HG, Lee YH, $\mathrm{Na}$ HJ, Lee DC, Kim HC, Choi I: TXNIP maintains the hematopoietic cell pool by switching the function of p53 under oxidative stress. Cell Metab 2013;18:75-85.

44 Joshi S, Wang W, Peck AB, Khan SR: Activation of the NLRP3 inflammasome in association with calcium oxalate crystal induced reactive oxygen species in kidneys. J Urol 2015;193:1684-1691. 